By ANNE M. SMITH

\title{
Reference Resources of British Columbia
}

Miss Smith is reference librarian of the University of British Columbia Library, Vancouver.

I SHALl attempt to give you a general survey of the reference resources of the province of British Columbia and to describe highlights in one or two libraries.

It may give you some idea of its size, if you consider that although British $\mathrm{Co}-$ lumbia could hold Texas, Idaho, and Massachusetts yet the total population for the whole province is somewhat less than that of Boston. Seventy per cent of the population is concentrated in the southwest corner-near Victoria, Vancouver, and the Fraser Valley.

With this background, you will not be surprised that we have so few libraries of any sort in the province. But you may be surprised to learn that I know of at least thirty small special libraries. These are not open to the public, nor are they administered by professional librarians. But since they serve a small group of men doing highly specialized research work they must be efficient, and do constitute a part of the reference resources of the province.

Far up the coast at Prince Rupert, the Fisheries Experimental Station of the Dominion Fisheries Research Board has a small library which is mainly for research in biochemistry, especially in refrigeration, vitamins and oils. The Pacific Biological Station library near Nanaimo is devoted largely to marine biology. This library holds many titles listed neither in the Union List of Serials and its supplements nor in the Library of Congress depository catalog, as well as others noted in the Union List as being held only by a few of the largest libraries on the continent.

Similarly in other fields there are small subject libraries not so distinguished, but serving specialists in varied fields. In Kamloops the library on insects affecting man and domestic animals is the best in Canada.

Omitting any further mention of these small special libraries, and the numerous private collections belonging to specialists, let us consider the libraries of New Westminster, Vancouver, and Victoria.

\section{New Westminster}

If you drive up the coast you will pass through the little town of New Westminster, called the Royal City, because it was named by Queen Victoria.

His Honour, Judge Howay, a distinguished historian, to whom I shall refer later, lives in New Westminster where he has assembled a notable library of early voyages to the Pacific coast. Although this collection is exceedingly valuable, it is, of course, not open to visitors.

\section{Vancouver}

Close to New Westminster lies Vancouver, where the public library is worth 
a visit. Here Edgar S. Robinson and his staff have done wonders in spite of the fact that the library is inadequately housed and starved financially. The art division is probably the best in a Canadian public library west of Toronto and the reference collection is especially strong in directories and yearbooks.

Apart from the general reference collection, there is a section devoted to northwest history, which covers, as well as British Columbia, a few important titles in the middle west on Canada and the United States, old Oregon and north California, Alaska and the Yukon. Several important files of British Columbia newspapers and periodicals are in the collection together with some 75 maps and 800 pamphlets mainly on British Columbia. A dozen typescripts, chiefly of important voyages to the northwest coast, not yet published, including a translation of Malaspina's Voyages, done for the library, are available. There is also an important original manuscript of David Thompson's describing an attempt to cross the Rocky Mountains in I8oI. It is in the handwriting of the explorer and is signed by him, and contains an interesting reference to public libraries in the introduction. Probably the most important section in the library is that which includes travels to the northwest coast. Most of the printed sources are to be found in original editions. Several hundred volumes on Indians are also included.

Naturally Vancouver city is well represented with reports of local bodies, pamphlets and a host of ephemeral material. A complete file of city directories, the earliest being 1874 , gives a record of city growth not otherwise available. In I 874 , the list, which is of Burrard Inlet, after recording the names of all whites, con- cludes with a single entry "and I 4 Chinamen."

\section{University of British Columbia}

The University of British Columbia, which by law is the only institution of higher learning in the province empowered to grant degrees, is composed of three faculties-arts and science, applied science and agriculture.

There are two theological colleges on the campus with their own libraries, and a branch of the Forest Products Laboratories of Canada, maintained by the Forest Service of the Department of Mines and Resources, which has its own research library.

The Library of the University of British Columbia is young. Its collections have been built with regard to the teaching needs of the institution. In I9I4 the initial collection was purchased by James Thayer Gerould. For a small library of I 20,000 volumes, the proportion devoted to proceedings and transactions of learned societies is high.

The library has what might be regarded as an excellent collection of seventeenth century French literature, is especially strong in biographies and memoirs for that period, and has an equally fine collection of nineteenth century French poetry. It contains, unquestionably, the best collection of French literature in Canada west of Toronto.

The government document collection is growing. We have a complete set of British Columbia sessional papers, a fairly good file of Canadian documents and the British parliamentary papers since I9I4. Thanks to the generosity of the United States government, we have many useful American documents. Possibly of greatest interest would be our collection of the 
documents of the other British dominions, as these are not so generally found in American libraries.

It is only of recent years that we have been organizing the government documents for effective use.

For a small library, I think our collection of bibliographies is probably very good. In this connection we are proud to have the catalog of the Bibliothèque $\mathrm{Na}$ tionale, the new edition of the British Museum catalog and to be one of three libraries in Canada to possess the depository catalog of the Library of Congress, which we find invaluable.

With the nucleus of the Carnegie Corporation gifts in music and art, the university library has built a useful, although not scholarly, reference collection in these fields. In the more scholarly field we do have the Propylaen Kunstgeschichte, the Michel Histoire de l'Art and the Van Marle History of Italian Painting.

A few blocks from the university library Dr. Robie L. Reid has a library of about 30,000 volumes devoted exclusively to Canadiana. Although this splendid collection is a private one, Dr. Reid has been exceedingly generous in permitting university students to use his library freely for research work.

There are three other libraries which might be mentioned in passing. The Vancouver City Hall houses the collection of city archives. Research students may also consult, by special arrangement, the libraries of the Vancouver Medical Association and the Law Library.

\section{Victoria}

In Victoria I might mention the high quality of the work being done in the public library, which is well worth a visit. Very wisely this library, although it has a fine general reference collection for a small public library, makes no attempt to compete with the provincial library in collecting research material. Indeed the two supplement one another admirably.

Another important library in British Columbia is the provincial library, which corresponds to a state library.

On September 23, I858, this library was voted its first appropriation of $£ 250$. Today it embraces four great divisions: (I) the main library which is a legislative reference library for the state departments and the legislative assembly, (2) the Pacific northwest history collection, (3) the archives, and (4) the extension services.

The legislative section has an extensive document collection: a complete British Hansard, a complete set of the Statutes of the Realm, the Journal of the British House of Commons from I 547, and a long file of British state papers. It has a very large collection of Canadian and provincial government publications, supplemented by a fine collection of imperial documents and the publications of the other dominions.

When I say that David Hunter Miller, historical adviser to the United States Department of State, and editor of the famous Treaties and International Acts of the United States of America (I93 I- ) resides in Victoria and uses the provincial library for his great work, I need say no more.

The main library has also a very fine newspaper collection which occupies onehalf mile of shelving. With the Toronto Public Library, it possesses the longest file of the New York Times in Canada; it has the London Times from I 839 and a complete file of British Columbia newspapers. Let me tell you the story of one.

In 1863 a souvenir edition of the Emi- 
grant Soldiers' Gazette, a manuscript newspaper published by the Royal Engineers on board the ship Rome City, was published by Colonel Wolfenden, later for many years king's printer. Only the one copy owned by the provincial library is known to exist. In 1908 a second souvenir edition was reprinted by Colonel Wolfenden from the first souvenir edition, which he neglected to return. When the king's printer died, an old iron chest, that he had brought around the Horn with him in 1858 , was taken from his office to his home, where it remained unopened for fifteen years, partly because the key was broken. In I936 Madge Wolfenden, the assistant archivist of the provincial library, presented the chest to the library on condition that the archives should pay for repairs. Within was found the first souvenir edition which had been missing for thirty years!

The main library in addition to a good general collection possesses a number of valuable rarities. There is a very fine Shakespeare collection, gathered at the time of the tercentenary. It includes two Shakespeare folios (second and fourth), later editions, books about the life and times, playbills, prints, autographs, etc. Other rare items in the main library, are for example, the first collected edition of Ben Jonson, the first collected edition of Beaumont and Fletcher, and a first edition, untrimmed, of Boswell's Life of Johnson. They were purchased from Harrison Garside.

The section of the library to which I wish to draw particular attention is the northwest history collection. It might be described as a definitive collection of northwest history and contains everything of note in first edition. It consists of about I 5,000 books and pamphlets to which may be added a great deal of supplementary material in the main library.

About I9I3 the province had paid off all the debts which could be paid off and had millions on deposit in the banks-incredible as that may seem today. At that time the librarian of the provincial library was Mr. E. O. S. Scholefield, who was preeminently a collector. He urged the importance of building up the northwest history collection before materials became scarce and prices high. Mr. Scholefield was practically given carte blanche and employed buying agents all over the world, with the result that when Lord Tweedsmuir, the Governor-General of Canada, visited the library recently, he commented on the fact that the collection was so complete and consisted of such fine copies.

I would like to mention only a few of the many rarities that this library possesses. It has a fine collection of atlases. Abraham Ortelius (i 572-98), the greatest geographer of the sixteenth century Flemish school, published in 1570 his chief work Theatrum Orbis Terrarum. The provincial library has the first edition of 1570 and three subsequent editions. It has a superb copy of the I 584 edition with handtinted maps.

The library has also a very fine Pieter Goos atlas and two fine copies of Linchoten. Good copies are almost priceless as Linchoten was used as a pilot's guide, and extant copies are usually in poor condition.

The provincial library has a splendid run of Hakluyt's famous Voyages, which are seldom found, as here, in first class condition. Although Queen Elizabeth and her advisers suppressed-very successfully on the whole-details about Sir Francis Drake's piratical exploits, to satisfy public curiosity Hakluyt inserted six 
unnumbered leaves in the 1589 edition. This rare and valuable edition is in the provincial library with two very fine copies of the I 598-I 600 edition, including the rare title-page, and also the I599-I600 edition.

There is a good collection of original matter relating to Drake, including two copies of Fletcher's $W$ orld Encompassed which was published in 1628 under the patronage of Drake's nephew. Needless to say the recent discovery of Drake's Plate of Brass in the San Francisco Bay region has greatly enhanced the authority of Fletcher's narrative. The collection also contains two copies of the I6I8 pamphlet Sir Francis Drake Revived.

You will probably recall that Samuel Purchas, an English clergyman who lived about 1600 and who is remembered for his travel books, inherited many of the manuscripts of Richard Hakluyt. His Pilgrimage is a continuation of Hakluyt's work. The provincial library has a particularly tall copy of the $1625-26$ edition in original boards except for rebacking.

There are over 300 items dealing exclusively with Captain Cook, covering all editions of Cook, other voyages and lives. The prize items of the Cook collection are the three editions of Zimmerman. It was he who published the first account of Cook's third voyage, the Nootka voyage. The first edition was published in Göttingen in $178 \mathrm{I}$, the second, also in German, in Mannheim in 1783 . Later in I 783 there was a French translation published in Berne. This library is one of two in the world to have all three editions. The other is the Mitchell Library of New South Wales. Seventeen copies of all three editions are known to collectors, of these the Mitchell library has five or six and the provincial library three.
The library has all editions of Captain Vancouver's works. The unique item of that collection is a private copy belonging to Hewitt, surgeon on one of Vancouver's ships, interleaved, specially bound, and with all his notes and comments. John Hewitt was one of two of the crew of the ship Boston not massacred by the Indians at Nootka. He was an armourer who was captured by the Indians, lived with them for three years, and during that period kept a diary. Goodspeed lists twenty items as a complete set of the editions of the Journal, Adventures, etc. The provincial library has twelve of the twenty items, including two that are rare: (I) the original edition of Jewitt's Journal ( 1808 ) and (2) the first edition of the Narrative ( 1815$)$.

\section{Archives}

Supporting the books on northwest history the archives division has a very large and fine collection of manuscripts and relics, for example, the dagger, which by tradition killed Captain Cook, and an autographed letter of Captain Vancouver.

One prized item is the original commission and instructions from Queen Victoria to Richard Blanshard, first governor of Vancouver Island.

\section{Conclusion}

In conclusion, permit me to restate the reference resources of the province in terms of the subject rather than of the library. To do so, I have used as a basis, Mr. Downs' Guide for the Description and Evaluation of Research Materials (1939). It was not possible to check carefully with this list more than the serials and large sets, and the latter only for the provincial and university libraries. 
Part one of Mr. Downs' Guide deals with general classes, such as general reference materials, bibliography, library science, dissertations, documents, manuscripts, newspapers, general periodicals and society publications, directories, illustrations and ephemerae. Part two deals with special subjects, which Mr. Downs divides into five large groups-the humanities, the social sciences, science, technology, and special collections.

To give you some idea of the standard adopted, I have used the term good only when 50 per cent or more of the titles listed in the Guide are held in the province.

On the whole the general classes of part one are moderately good, if it is understood that the greatest emphasis for manuscripts, directories, newspapers and documents is on Canadian material.
The reference resources in the humanities are only fair. It must be admitted that the province is incomparably stronger in English than in any other language.

In the social sciences, the holdings are also only fair, although international relations, education and biography might be described as very good. Anthropology is weak, as is history, except in teaching fields.

The field of science is probably the best, although pharmacy and dentistry are conspicuous by their absence. In the province we have, for example, twelve of the thirteen serials listed for geology, four of six for astronomy, eight of nine for physics, fourteen of nineteen for chemistry and ten of twelve in medicine. Similarly for large sets, we have two of three in physics and three of five in chemistry.

The field of technology is well represented in engineering and agriculture.

\section{Essentials of a University Library Building}

\section{(Continued from page 56)}

There would be certain advantages in having a librarian who was more of an instructor than a librarian to direct the program of the lower divisional room. She could see to it that each beginning student learned how to use bibliographic tools and she could work with each one individually.

Sixth, the administration of such a system may seem complex at first, but actually it is much simpler than the one now in vogue. It has the further advantage of making possible the separation of professional from clerical duties. It may be somewhat more expensive than the present one, but if it accomplishes what it at- tempts to do, no one will grumble about the cost.

The purpose of this discussion was to demonstrate that university library planning appears to have fallen into a rut and that a fresh critical examination of the fundamental assumptions is much to be desired. A complete analysis of the suggestions proposed was not intended. Those of you who are interested can watch the success of this experiment at the University of Colorado where our new library building is embodying most of the ideas mentioned in this paper. 